\title{
MAGE Genes mRNAs: Potential Early Diagnostic Markers for Hepatocellular Carcinoma in HCV Saudi Patients
}

\author{
Hussein $\mathrm{YM}^{1 \& 2}$, Hashim $\mathrm{AA}^{3}$, Alzahrani $\mathrm{SS}^{4}$, Alhazmi $\mathrm{AS}^{1}$, Hawash $\mathrm{YA}^{1 \& 5}$, \\ Eed $\mathrm{EM}^{1 \& 6}$, Shalaby $\mathrm{SM}^{2}$ \\ ${ }^{I}$ Medical Laboratories Department, Faculty of Applied Medical Sciences, Taif University, Saudi Arabia \\ ${ }^{2}$ Medical Biochemistry Department, Faculty of Medicine, Zagazig University, Egypt \\ ${ }^{3}$ Medical Biochemistry Department, Faculty of Pharmacy, Taif University, Saudi Arabia \\ ${ }^{4}$ Community Medicine Department, Faculty of Medicine, Taif University, Saudi Arabia \\ ${ }^{5}$ Medical Parasitology Department, National Liver Institute, Menoufia University, Egypt \\ ${ }^{6}$ Medical Microbiology \& Immunology Department, Faculty of Medicine, Menoufia University, Egypt
}

\begin{abstract}
In recent years, several different multi-marker assays have been developed for the detection of HCC cells in the peripheral blood. This study included 89 Saudi patients with chronic HCV and 30 ages and sex matched healthy control subjects. MAGE-1 mRNA was expressed in the peripheral blood of 3(13.6\%) patients with localized HCC and in 9(40.9\%) patients with metastatic HCC. MAGE-3 mRNA was expressed in the peripheral blood of 3(13.6\%) patients with localized HCC and in $8(42.1 \%)$ patients with metastatic HCC. Also, MAGE-4 mRNA was expressed in the peripheral blood of 4(18.1\%) patients with localized HCC and in 10(52.6\%) patients with metastatic HCC.All control subjects showed no expression of any MAGE mRNAs. In conclusions, MAGE-1, MAGE-3 and MAGE-4 may be promising diagnostic tools for monitoring the prognosis of HCC patients and for early detection of circulating metastasis of HCC cells.
\end{abstract}

Keywords: MAGE-1, MAGE-3, MAGE-4, HCC

\section{Introduction}

Infection by hepatitis $\mathrm{C}$ virus $(\mathrm{HCV})$ is one of the most common causes of chronic liver disease worldwide. The World Health Organization (WHO) has recorded that 170 million persons have chronic HCV infections and more than 3 million persons get new infections annually. Chronic HCV infection has a high risk of progression to cirrhosis and hepatocellular carcinoma [1]. The underlying pathogenic mechanisms by which $\mathrm{HCV}$ contributes to liver cell transformation remain unclear. One possibility is that the development of HCC may be related to chronic necro-inflammatory effects and subsequent cirrhosis as $97 \%$ of patients with HCV markers and HCC have cirrhosis and the most of the remainders develop HCC in the presence of chronic hepatitis $[2,3]$.

Hepatocellular carcinoma (HCC) is one of the most prevalent malignancies; it is the sixth most common cancer and the third most common cause of cancer mortality worldwide [4]. However, there is a worldwide variation in the incidence of HCC; this variation has a strong correlation with the prevalence of chronic HBV and HCV [5]. The possible synergistic relationship of hepatitis B virus (HBV) and HCV as risk factors for progression of cirrhosis to HCC continues to be of interest [6]. In Saudi Arabia, HCC constitutes one of the most common malignant tumors where, antibody to HCV (anti-HCV IgG) is detectable in about $1-3 \%$ of the general population [7]. Many reports indicated that HBV was causally associated with HCC in Saudi Arabia but the risk attributable to $\mathrm{HCV}$ was rarely estimated [8].

Although the regular liver ultrasonic examination and measuring serum alpha-fetoprotein (AFP) level can detect small HCC at the early stages, the recurrence and metastasis are frequent and the prognosis remains unsatisfactory. The high recurrence rate may be attributed to dissemination of HCC cells into the circulation and their proliferation in the immunosuppressive environment. This dissemination of $\mathrm{HCC}$ cells into the circulation plays a critical role in post-operative recurrence and metastasis [9]. Partial hepatectomy is considered to be the most appropriate treatment for selected patients with HCC without cirrhosis. While, liver transplantation is established as the gold standard for patients with cirrhosis in the absence of extra-hepatic spread. Local regional therapy is indicated in selected patients who are not eligible for surgery [10]. Early detection of metastatic tumor cells is critical issue to identify HCC patients at high risk of relapse. However, it is difficult to detect such HCC cells with the conventional techniques [11]. Serum level of alpha feto-protein (AFP) is a good biomarker for HCC however; it does not specifically differentiate between metastasis and local HCC. Previously both albumin and AFP mRNA were widely used as tumor markers for HCC cells in circulation. However, their reliability has been decreased because both albumin and AFP mRNA are abundantly expressed in normal liver 
cells and they are released in the peripheral blood by either surgical injury of the liver or by diseases other than HCC [12].

The human MAGE genes are on the $\mathrm{X}$ chromosome and are organized in three loci named MAGE-A (12 genes, Xq28), MAGE-B (4 genes, Xq21.3) and MAGE-C (1 gene, Xq26). Also, a fourth human MAGE gene representing a new locus was isolated and named MAGE-D. This gene was located in the Xq11.23 region [13]. Despite the numerous numbers of isolated MAGE genes, their physiological function in normal tissues remains unknown [14]. The MAGE-A subfamily comprises 12 genes (MAGE-A1 to MAGE-A12) which are expressed in various types of malignancies, but not in normal adult tissues, except for testis and placenta. The MAGE-A genes are of particular interest for anti-tumor immunotherapy because their antigens are strictly tumor specific. MAGE-1 is a member of MAGE-A genes that is not expressed in normal tissues except testis. Also, mRNA was detected in human skin after wounding and in normal ovarian tissue in premenopausal women. MAGE-1 is highly expressed in small HCC so it is used for differentiating non malignant nodules from small and well differentiated HCC. It is expressed in HCC even in AFP-negative patients [15]. MAGE-3 belongs to MAGE-A gene family and is expressed in many tumors and is silent in normal somatic cells except male germ line cells [16]. Discrimination between HCC and non-cancerous lesions and how to suppress the recurrences are issues of great interest. Detection of MAGE transcripts in peripheral blood mononuclear cells (PBMC) may be helpful in early prediction of the relapse and prognosis of the HCC patients. In the present study, reverse transcription polymerase chain reaction (RT-PCR) had been carried out for MAGE-1, MAGE-3 and MAGE-4 mRNAs to evaluate their efficacy as new markers for early detection of HCC metastases in HCV infected Saudi patients.

\section{1. $\quad$ Subjects}

\section{Subjects and methods}

The study included 89 Saudi patients with chronic HCV infection confirmed by real time PCR testing for HCV RNA (28 patients with chronic HCV infections without cirrhosis, 20 patients with chronic HCV infections complicated with cirrhosis, 22 patients with localized HCC, and 19 patients with metastatic HCC) in addition to thirty age and sex-matched healthy controls. Post-chronic HCV hepatitis cirrhosis group was selected according to the clinical and laboratory examination (grade $\mathrm{B}$ and $\mathrm{C}$ according to child-pugh classification). HCV patients with single localized HCC group were selected by abdominal ultrasonic examinations then was confirmed by triphasic computed tomography (CT) and AFP level while, patients with multiple focal lesion and/or portal vein thrombosis were excluded, distant metastases had been excluded by chest and abdominal CT and isotopic bone scan. Patients with HCC with distant and/or macro-vascular metastasis $(n=20)$ were selected from patients who presented metastases during selection of the previous group (Table 1).

\subsection{Methods}

\subsubsection{Blood samples}

Blood samples were drawn from all subjects after 8 hours fasting. Approximately $10 \mathrm{ml}$ of blood from each patient were collected in two tubes, $5 \mathrm{ml}$ in heparinized tube for separation of peripheral blood mononuclear cells (PBMC). Another $5 \mathrm{ml}$ were collected in plain tubes for the separation of serum.

\subsubsection{Isolation of peripheral blood mononuclear cells}

PBMCs were isolated from blood by density gradient centrifugation using Ficoll hypaque 1077 (Sigma, USA) at $1200 \mathrm{~g}$ for $30 \mathrm{~min}$ at $4{ }^{\circ} \mathrm{C}$. The interface cells were removed, washed twice with $25 \mathrm{ml}$ of sterile PBS (pH7.3), pelleted, and re-suspended in $1 \mathrm{ml}$ of PBS. The cells were pelleted again at $1200 \mathrm{~g}$ for 2 minutes. Then pellets were kept at $-70{ }^{\circ} \mathrm{C}$ until RNA extraction.

\subsubsection{Biochemical measurements}

Albumin, alanine aminotransferase (ALT), aspartate aminotransferase (AST), urea, and creatinine were measured in serum by routine enzymatic methods (Spinreact). Serum AFP concentration was measured by ELISA assay according to the manufacturer's recommendation using Elecsys 2010 (Roche Diagnostics Gmbh, D-68298 Mannheim). HCV antibodies were measured by ELISA using the commercially available Murex anti$\mathrm{HCV}^{\text {th }}{ }^{\text {generation }}$ (DiaSorin, S. P. A. UK) (Table 2).

\subsubsection{RNA extraction}

Total RNA of PBMCs was extracted using RNA extraction kit (Qiagen) according to the manufacturer's instruction. The isolated RNA was re-suspended in RNAse-free water and stored at $-70^{\circ} \mathrm{C}$ until assay. The cDNA was reverse transcribed in a $10 \mu 1$ mixture containing $6 \mu 1$ of total RNA, $0.5 \mu 1$ random primers (Promega, Madison), $2 \mu$ l of reverse transcriptase buffer (Life Technology, Gaithersburg, MD), $1 \mu 1$ of 
deoxyribonucleoside triphosphate (dNTP) mixtures $(10 \mathrm{Mm})$, and $0.5 \mu \mathrm{l}$ of AMV reverse transcriptase (5 U/ $\mu 1)$. The mixture was incubated at $37^{\circ} \mathrm{C}$ for $10 \mathrm{~min}, 52^{\circ} \mathrm{C}$ for $45 \mathrm{~min}, 95^{\circ} \mathrm{C}$ for $5 \mathrm{~min}$, then in ice bath for $5 \mathrm{~min}$.

\subsubsection{RT-PCR}

Detection of MAGE-3 and MAGE-4 mRNA were done according to Chen et al. [17] The amplification reaction contained $2.5 \mu \mathrm{l} \mathrm{cDNA}, 0.5 \mu \mathrm{l}$ each of $5 \mu \mathrm{M}$ primers, $5 \mu \mathrm{l}$ of Taq polymerase (GIBCO BRL), and 0.5 $\mu 1$ of dexoyribonucleoside triphosphate (dNTP) mixtures $(10 \mathrm{Mm})$ in buffer solution. The sequences of primers for PCR amplification were as shown in (Table 3).

PCR was performed at $96^{\circ} \mathrm{C}$ for $5 \mathrm{~min}$ followed by 35 cycles of $94^{\circ} \mathrm{C}$ for $1 \mathrm{~min}, 68^{\circ} \mathrm{C}$ for $2 \mathrm{~min}$, and $72^{\circ} \mathrm{C}$ for 4 $\mathrm{min}$; then $15 \mathrm{~min}$ of final extension at $72^{\circ} \mathrm{C}$ for MAGE-1 and MAGE-3 and $94^{\circ} \mathrm{C}$ for $30 \mathrm{~s}, 58^{\circ} \mathrm{C}$ for $30 \mathrm{~s}$, and $74^{\circ} \mathrm{C}$ for $30 \mathrm{~s}$, then $15 \mathrm{~min}$ of final extension for MAGE-4. The PCR products were separated in $2 \%$ agarose gel stained by ethidium bromide.

\subsubsection{Statistical analysis}

The results for continuous variables are expressed as Means $\pm \mathrm{SD}$. The means of the all groups were compared in a one-way analysis of variance. The statistical significances of differences in frequencies of variants between the groups were tested using the chi-square $\left(x^{2}\right)$ test. A difference was considered significant at $\mathrm{P}<0.05$. All data were evaluated using SPSS software version 16.0 for windows.

\section{Results}

Results showed variation in AFP levels among different groups (Table 2); where the maximal level detected in metastatic HCC group followed by localized HCC group (Mean \pm SD were $681 \pm 328.4$ and 155.5 $\pm 72 \mathrm{ng} / \mathrm{ml}$ respectively). Although HCC patients with a high level of serum AFP exhibited detectable concentrations of MAGE-3and 4 mRNAs more often than those with a low serum AFP level, there is no significant difference. MAGE-1, MAGE-3 and MAGE-4 mRNAs were positively expressed in peripheral blood of localized HCC patients in $13.3 \%(3 / 22) 13.6 \%(3 / 22)$ and $18.1 \%(4 / 22)$ respectively; moreover, when combining the results of the mRNAs expression (i.e. Expression of MAGE-1 and/or MAGE-3 and/or MAGE-4) in patients with localized HCC, the rate increased up to $36.3 \%(8 / 22)$. The patients who had MAGE-3 or MAGE-4 mRNAs $(n=5)$ in their peripheral blood were under surgical resection $(n=1)$, ablation by radiofrequency and/or absolute alcohol injection $(\mathrm{n}=3)$ and selective chemoembolization $(\mathrm{n}=1)$. MAGE-1, MAGE-3 and MAGE-4 mRNAs were positively expressed in peripheral blood of metastatic HCC patients in $42.1 \%$ (8/19), 40.9\% (9/22) and 52.6\% (10/19) respectively. Also combined expression results of MAGE-1, MAGE-3 and MAGE-4 mRNAs in the peripheral blood of patients with metastatic HCC, the rate was increased to78.9\% (Table 4).

\section{Discussion}

$\mathrm{HCC}$ is one of the most common malignant tumors; representing more than 5\% of all cancers [18]. HCC is the second among cancers of the digestive tract after stomach cancer [19]. Metastatic spread through blood vessels to secondary sites is the most important factor affecting the prognosis of HCC. If the metastatic HCC cells could be sensitively and specifically determined at the early stages, more beneficial therapeutic methods could be used [20].

The two frequently used markers in detection of HCC; albumin and AFP mRNAs were shown to be expressed in blood of patients with hepatitis, liver cirrhosis, and infective viral hepatitis [3].Reverse transcriptase polymerase chain reaction (RT-PCR) amplification of genes expressed by the tumor is considered the method with the highest diagnostic sensitivity allowing the identification of one tumor cell in up to $10^{7}$ normal cells in many sources as blood, bone marrow or lymph nodes [21, 22].

MAGE gene transcripts have been regarded as tumor specific markers and were found to be highly expressed in many histological types of cancers [23]. The MAGE-3 and MAGE-4 genes are members of the cancer/testis (CT) antigen family used as cancer-specific markers. It has been reported that MAGE-3 and MAGE-4 mRNAs are positive in HCC tissue, but there is no MAGE expression in peri-cancerous tissue, hepatitis, cirrhosis, or normal liver tissue [20, 24].

The aim of this work was to detect occult hematogenous metastasis of HCC cells by RT-PCR of MAGE-1, MAGE-3 and MAGE-4 transcripts and to combine these markers with each other to detect HCC cells in the peripheral blood in order to elevate their sensitivity and specificity.

Our results showed that the positive rate of expression MAGE-1, MAGE-3 and MAGE-4 mRNAs were significantly increased in the peripheral blood of metastatic HCC patients than patients with localized HCC, one patient with chronic HCV and one cirrhotic patient were positive for one MAGE type (MAGE-4 and MAGE-3 respectively). While none of them were positive for (MAGE-1 mRNA. Also, none of controls showed expression of MAGE-1, MAGE-3 or MAGE-4 mRNAs in their peripheral blood. MAGE-1was expressed in the 
blood in $13.6 \%$ of patients with localized HCC and in $40.9 \%$ of patients with metastatic HCC. Expression of MAGE-3 mRNA was detected in the blood in $13.6 \%$ of patients with localized HCC and in $42.1 .8 \%$ of patients with metastatic HCC. These results are in accordance with Zhang et al. who found that MAGE-1and MAGE-3 was expressed in $14.0 \%$ and $20.1 \%$ respectively in peripheral blood of HCC patients and $60.5 \%$ in HCC tissues [25]. Also Mou et al. reported that MAGE-3 was expressed in 33.3\% in peripheral blood of HCC patients and $53.3 \%$ in HCC tissues [24]. MAGE-4 mRNA was expressed in the peripheral blood of 52.6\% of patients with metastatic HCC and in $18.1 \%$ of patients with localized HCC. Tahara et al. reported that MAGE-4 mRNA was expressed in 18\% HCC tissues [20]. On contrary to our results, Tsuzurahara et al. showed that MAGE-4 protein was significantly increased in HCC and in HCV-related cirrhotic liver patients [26].

Combined expression results of MAGE-1, MAGE-3 and MAGE-4 mRNAs in the peripheral blood of metastatic HCC patients showed increased rate to $78.9 \%$, which is significantly higher than that of any single marker. Also, by combined expression results of MAGE-1, MAGE-3 and MAGE-4 mRNAs in the peripheral blood of localized HCC patients; the rate was increased to $36.3 \%$, which is significantly higher than the $13.6 \%$, 13.6 and $18.1 \%$ of the patients who were positive only for MAGE1, MAGE-3 or MAGE-4 mRNA respectively. So, combining detection of MAGE-1, MAGE-3 and MAGE-4 mRNAs in PBMCs provide high sensitivity and specificity in detecting tumor cells in the blood. Our results showed not only that the positive rate of expression MAGE genes is markedly increased in peripheral blood of metastatic HCC patients than in peripheral blood of localized HCC patients, but also follow-up of localized HCC patients with at least positive one of MAGE mRNA showed signs of occurrence of metastasis. So MAGE-1, MAGE-3 or MAGE-4 mRNA expression in peripheral blood of in patients with localized HCC may be helpful in early detection of circulating cancer cells and consequently early identification of distant metastasis. Due to the fact that blood dissemination is the main metastatic route for HCC [27], identifying circulating cancer cells may be helpful in detecting the prognosis, guiding the treatment and reducing the recurrence rate of $\mathrm{HCC}[28]$.

\section{Conclusion}

Early detection of circulating metastatic HCC cells is an important factor in therapy protocol development of cancer-specific multi-marker assay.MAGE-1, MAGE-3 and MAGE-4 were found to be a promising tool for early detection of occult hematogenous metastasis of $\mathrm{HCC}$ with good sensitivity and specificity.

\section{Acknowledgments} $1-434-2790$.

This study was funded with the support of academic research centre in Taif University, project number

\section{References}

[1] Shepard CW, Finelli L and Alter MJ. Global epidemiology of hepatitis C virus infection. Lancet Infect Dis. 5,2005, 558-67.

[2] Micheilsen PP, Francque SM and Van Dongen JL. Viral hepatitis and hepatocellular carcinoma. World J SurgOncol.3, 2005, 279.

[3] Yano M, Yatuhashi $\mathrm{H}$ and Inoue O. Epidemiology and long-term prognosis of hepatitis C virus infection in Japan. Gut.34 (suppl),1996, 13-16.

[4] Alshehri A. Hepatitis B and C Viruses incidence, the Risk Factors of Hepatocellular Carcinoma, is low in Aseer Region, Saudi Arabia. Egypt. Acad. J. biolog. Sci.5(1), 2013,7-18.

[5] Okuda K. Hepatocellular carcinoma: Recent progress. Hepatology.15, 1992, 948-63.

[6] Baker PA, Salehi A. The MAGE proteins: emerging roles in cell cycle progression, apoptosis, and neurogenetic disease. J Neurosci Res. 67, 2002, 705-12.

[7] Faleh FZ, Ramia S, Arif M et al. Profile of hepatitis C virus and the possible modes of transmission of the virus in the Gizan area of Saudi Arabia: a community based study. Ann. Trop. Med. Parasitol. 89, 1995, 431-7.

[8] Ephraim A AandMohmmed OG. Hepatocellular carcinoma in Saudi Arabia: Role of hepatitis B and C Infection. J. Gastroenterol \&Hepatol.19, 2004, 665-4.

[9] Sakon M, Nagano H, Nakamori S, Dono K, Umeshita K, Mrakami T, et al. Intrahepatic recurrences of hepatocellular carcinoma after hepatectomy: analysis based on tumor hemodynamics. Arch Surg. 137, 2002, 94-9.

[10] Abrams P, Marsh JW. Current approach to hepatocellular carcinoma. Surg Clin North Am. 90(4), 2010, 803-16.

[11] Hussein YM, Ghareib AF, Mohamed RH, Radwan MI and Elsawy WH. MAGE-3 and MAGE-4 genes as possible markers for early detection of metastases in hepatitis C virus Egyptian patients complicated by hepatocellular carcinoma. Med Oncol. 29, 2012, :994-5.

[12] Wong IH, Leung T, Ho S, Lau WY, Chan M, Johnson PJ. Semiquantitation of circulating hepatocellular carcinoma cells by reverse transcriptase polymerase chain reaction. Br J Cancer.76(5), 1997, 628-33.

[13] Hennuy B, Reiter E, cornet A, Bruyninx M, daukandt M, houssa P, N'Guyen VH, Closset J and Hennen G. A Novel Messenger Ribonucleic Acid Homologous to Human MAGE-D is Strongly Expressed in Rat Sertoli Cells and Weakly in Leydig Cells and is Regulated by Follitropin, Lutropin and Prolactin, Endocrinology 141(10), 2000, 3821-10.

[14] Nagao T, Higashitsuji H, Nonoguchi K, Sakurai T, Dawson S, Mayer RJ, et al. MAGE-A4 interacts with the liver oncoproteingankyrin and suppresses its tumorigenic activity. J Biol Chem. 278 (12), 2003, 10668-74.

[15] Teama SH Agwaa SH, Noha A. ElNakeeb NA, Abdel Hamid M, Maher AM, Mourad M and Heidar MM: Multiple molecular markers MAGE-1, MAGE-3 and AFP mRNAs expression nested PCR assay for sensitive and specific detection of circulating hepatoma cells: Enhanced detection of hepatocellular carcinoma. The Egyptian Journal of Medical Human Genetics. 14, 2013, 2128 . 
[16] Kariyama K, Higashi T, Kobayashi Y, Nouso K, Nakatsukasa H, Yamano T, et al. Expression of MAGE-1 and -3 genes and gene products in human hepatocellular carcinoma. Br J Cancer.81(6), 1999, 1080-7.

[17] Chen CH, Huang GT, Lee HS, Yang PM, Yan MD, Chen DS, et al. High genes frequency in human of expression of MAGE hepatocellular carcinoma. Liver.19, 1999, 110-4.

[18] Bruix J, Sherman M, Llovet JM Beaugrand M lencioni R, Burroughs AK, Christensen E, PagliaroL, Colombo M and Rodes J. EASL panel of Experts on HCC: Clinical management of hepatocellular carcinoma. Conclusions of the Barelona-2000 EASL conference.J Hepatol.35, 2001, 421-9.

[19] Bosch FX, Ribes J and Borras J. Epidemiology of primary liver cancer. Semin Liver Dis. 1999;19:271-8.

[20] Tahara K, Mori M, Sadanaga N, Sakamoto Y, Kitano S, Makuuchi M. Expression of the MAGE gene family in human hepatocellular carcinoma. Cancer. 85, 1999, 1234-40.

[21] Houghton RL, Dillon DC, Molesh DA, Zehentner BK, Xu J, Jiang J, et al. Transcriptional complementarity in breast cancer: application to detection of circulating tumor cells. MolDiagn.6(2), 2001, 79-11.

[22] Berois N, VarangotM, Aizen B, Estrugo R, Zarantonelli L, Ferna'ndez P, et al. Molecular detection of cancer cells in bone marrow and peripheral blood of patients with operable breast cancer. Comparison of CK19, MUC1 and CEA using RT-PCR.Eur J Cancer.36(6), 2003, 717-23.

[23] Hussein YM, Morad FE, Gameel MA, Emam WA, El SawyWH,El-TarhounySA,Bayomy, ESandRaafat N.MAGE-4 gene m-RNA and TGF in blood as potential biochemical markers for HCC in HCV-infected patients. Med Oncol.29 (5), 2012,3055 -62.

[24] Mou DC, Cai SL, Peng JR, Wang Y, Chen HS, Pang XW, et al. Evaluation of MAGE-1 and MAGE-3 as tumour-specific markers to detect blood dissemination of hepatocellular carcinoma cells. Br J Cancer.86, 2002, 110-16.

[25] Yuasa T, Okamoto K, Kawakami T, Mishina M, Ogawa O, Okada Y. Expression patterns of cancer testis antigens in testicular germ cell tumors and adjacent testicular tissue. J Urol. 165, 2001, 1790-4.

[26] Tsuzuraharsa S, Sata M, Iwamoto O, Shichijo S, Kojiro M, Tanikawa K, et al. Detection of MAGE-4 protein in the sera of patients with hepatitis-c virus-associated hepatocellular carcinoma and liver cirrhosis. J Cancer Res. 88, 1997, 915-8.

[27] Imamura H, Matsuyama Y, Tanaka E, Ohkubo T, Hasegawa K, Miyagawa S, et al. Risk factors contributing to early and late phase intrahepatic recurrence of hepatocellular carcinoma after hepatectomy. J Hepatol.38, 2003, 200-7.

[28] Yanaga K. Current status of hepatic resection for hepatocellular carcinoma. J Gastroenterol.39, 2004, 919-26.

\section{Tables}

Table (1) Demographic information of the studied groups

\begin{tabular}{|c|c|c|c|c|c|}
\hline & $\begin{array}{l}\text { Control group } \\
(\mathrm{n}=30)\end{array}$ & $\begin{array}{l}\text { HCV without cirrhosis } \\
(\mathrm{n}=28)\end{array}$ & $\begin{array}{l}\text { HCV with cirrhosis } \\
(\mathrm{n}=20)\end{array}$ & $\begin{array}{l}\text { Localized HCC } \\
(\mathrm{n}=22)\end{array}$ & $\begin{array}{l}\text { Metastatic HCC } \\
(\mathrm{n}=19)\end{array}$ \\
\hline $\begin{array}{c}\text { Age } \\
(\text { Mean } \pm \text { SD) }\end{array}$ & $51.6 \pm 7.5$ & $48.6 \pm 2.5$ & $50.7 \pm 5.5$ & $54.2 \pm 6.5$ & $56.3 \pm 8.1$ \\
\hline $\begin{array}{l}\text { Gender } \\
\text { Male } \\
\text { Female }\end{array}$ & $\begin{array}{l}20(66.7 \%) \\
10(33.3 \%)\end{array}$ & $\begin{array}{l}16(57.1 \%) \\
12(42.9 \%)\end{array}$ & $\begin{array}{l}12(60.0 \%) \\
8(40.0 \%)\end{array}$ & $\begin{array}{l}13(59.1 \%) \\
9(40.9 \%)\end{array}$ & $\begin{array}{l}12(63.1 \%) \\
7(36.9 \%)\end{array}$ \\
\hline
\end{tabular}

ANOVA test.revealed no significant difference $(\mathrm{p}>0.05)$

Table (2) Serum AFP, ALT, AST\& Albumin levels in different studied groups

\begin{tabular}{|l|l|l|l|l|l|}
\hline & $\begin{array}{l}\text { Control group } \\
(\mathrm{n}=30)\end{array}$ & $\begin{array}{l}\text { HCV without } \\
\text { cirrhosis } \\
(\mathrm{n}=28)\end{array}$ & $\begin{array}{l}\text { HCV with cirrhosis } \\
(\mathrm{n}=20)\end{array}$ & $\begin{array}{l}\text { Localized HCC } \\
(\mathrm{n}=22)\end{array}$ & $\begin{array}{l}\text { Metastatic } \\
\text { HCC } \\
(\mathrm{n}=19)\end{array}$ \\
\hline AFP (ng/ml) & $3.1 \pm 1.3$ & $6.5 \pm 7$ & $131 \pm 41^{\mathrm{a}}$ & $155 . \pm 72^{\mathrm{a}}$ & $681 \pm 328.4^{\mathrm{a}, \mathrm{b}}$ \\
\hline ALT (IU/L) & $26 \pm 2$ & $102.5 \pm 37^{\mathrm{a}}$ & $40 \pm 31$ & $65 \pm 30.7^{\mathrm{a}}$ & $58.2 \pm 19.2^{\mathrm{a}}$ \\
\hline AST(IU/L) & $22 \pm 6$ & $72.5 \pm 37$ & $42 \pm 37^{\mathrm{a}}$ & $61 \pm 37^{\mathrm{a}}$ & $83.3 \pm 34.3^{\mathrm{a}}$ \\
\hline Albumin (g/dl) & $4 \pm 1.2$ & $3.5 \pm 4.0$ & $2.5 \pm 0.7$ & $2.1 \pm 0.5^{\mathrm{a}}$ & $1.7 \pm 0.5^{\mathrm{a}, \mathrm{b}}$ \\
\hline
\end{tabular}

${ }^{a}$ Significant difference from control group

${ }^{\mathrm{b}}$ Significant difference from cirrhosis group.

Table (3) Sequences of primers for PCR amplification MAGE mRNAs

\begin{tabular}{|l|l|}
\hline Gene & The primer \\
\hline \multirow{2}{*}{ MAGE-1 } & Sense, 5'-TAGAGTTCGGCCGAAGGAAC-3' \\
\cline { 2 - 2 } & Antisense, 5'-CTGGGCAATGAAGACCCACA-3'. \\
\cline { 2 - 2 } & Sense, 5'-TGGAGGACCAGAGGCCCCC-3' \\
\cline { 2 - 2 } & Antisense, 5'-GGACGATTATCAGGAGGCCTGC-3'. \\
\cline { 2 - 2 } & Sense,5'-ACCAAGGAGAAGATCTGCCAGTGGGTCTC-3' \\
\cline { 2 - 2 } MAGE-4 & Antisense, 5'-GTCGCCCTCCATTGCATTGTGC-3'. \\
\hline
\end{tabular}

Table (4) Expression of MAGE-1, MAGE-3\&MAGE-4 mRNAs enrolled groups

\begin{tabular}{|l|l|l|l|l|l|}
\hline & $\begin{array}{l}\text { Control group } \\
(\mathrm{n}=30)\end{array}$ & $\begin{array}{l}\text { HCV without cirrhosis } \\
(\mathrm{n}=28)\end{array}$ & $\begin{array}{l}\text { HCV with cirrhosis } \\
(\mathrm{n}=20)\end{array}$ & $\begin{array}{l}\text { Localized HCC } \\
(\mathrm{n}=22)\end{array}$ & $\begin{array}{l}\text { Metastatic HCC } \\
(\mathrm{n}=19)\end{array}$ \\
\hline MAGE-1 & 0 & 0 & 1 & $3(13.3 \%)^{\mathrm{a}}$ & $9(40.9 \%)^{\mathrm{a}, \mathrm{b}}$ \\
\hline MAGE-3 & 0 & 1 & 0 & $3(13.6 \%)^{\mathrm{a}}$ & $7(36.8 \%)^{\mathrm{a}, \mathrm{b}}$ \\
\hline MAGE-4 & 0 & 0 & 1 & $4(18.1 \%)^{\mathrm{a}}$ & $10(52.6 \%)^{\mathrm{a}, \mathrm{b}}$ \\
\hline Combined $^{*}$ & 0 & 1 & 1 & $8(36.3 \%)^{\mathrm{a}}$ & $15(78.9 \%)^{\mathrm{a}, \mathrm{b}}$ \\
\hline
\end{tabular}

*Combined results i.e. MAGE1and/or MAGE3 and/or MAGE4

${ }^{a}$ Significant difference from control group

${ }^{\mathrm{b}}$ Significant difference from localized HCC group 